\title{
Humanization practices in the parturitive course from the perspective of puerperae and nurse-midwives
}

\author{
Práticas de humanização no transcurso parturitivo na ótica de puérperas e enfermeiras obstétricas \\ Prácticas de humanización en el curso del parto desde la perspectiva de las puérperas y matronas
}

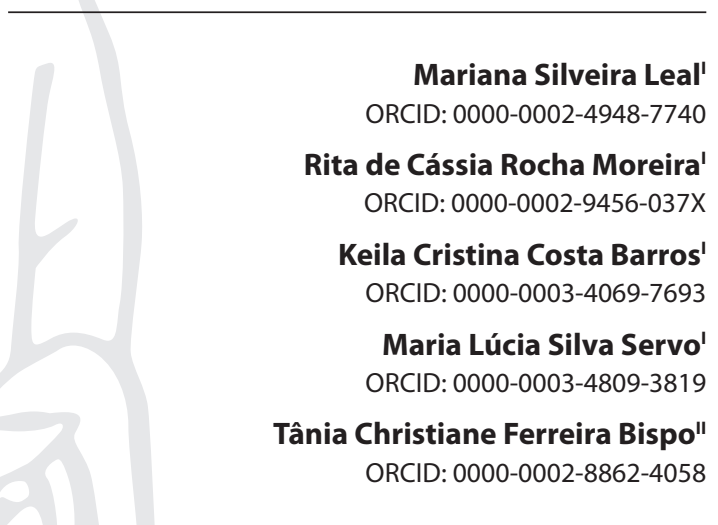

'Universidade Estadual de Feira de Santana. Feira de Santana, Bahia, Brazil.

"Universidade do Estado da Bahia. Salvador, Bahia, Brazil.

How to cite this article: Leal MS, Moreira RCR, Barros KCC, Servo MLS, Bispo TCF. Humanization practices in the parturitive course from the perspective of puerperae and nurse-midwives. Rev Bras Enferm. 2021;74(Suppl 4):e20190743. doi: http://dx.doi.org/10.1590/0034-7167-2019-0743

\section{Corresponding author:}

Mariana Silveira Leal

E-mail: marianaleal.enf@hotmail.com

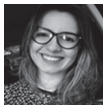

EDITOR IN CHIEF: Antonio José de Almeida Filho ASSOCIATE EDITOR: Maria Isabel Salamanca

Submission: 03-26-2020 Approval: 10-03-2020

\section{ABSTRACT}

Objective: to understand humanization practices in the parturitive course from the point of view of purperae and nurse-midwives. Methods: an exploratory, descriptive, qualitative research carried out in a maternity hospital in Bahia State. Semi-structured interviews were carried out, with a structured script applied to 11 mothers and 5 nurse-midwives from March to June 2019. Analysis followed Bardin's content structure. Results: this study unveiled the importance of using soft care technologies, respect for female role, active participation and women's autonomy as a positive impact on the parturition process. Final considerations: nurse-midwives are qualified professionals to assist women in labor and birth. They can favor the implantation and implementation of care with humanization practices, respect for women's choices and incentive to the normal way of delivery with an expanded view of individual and multidisciplinary needs.

Descriptors: Humanization of Assistance; Labor, Obstetric; Humanizing Delivery; Nurse Midwives; Women.

\section{RESUMO}

Objetivo: compreender as práticas de humanização no transcurso parturitivo na ótica de puérperas e enfermeiras obstétricas. Métodos: pesquisa exploratória, descritiva, qualitativa, desenvolvida em uma maternidade no estado da Bahia. Realizaram-se entrevistas semiestruturadas, com um roteiro estruturado aplicado a 11 puérperas e 5 enfermeiras obstétricas no período de março a junho de 2019. A análise seguiu a estrutura de conteúdo de Bardin. Resultados: o estudo desvelou a importância do uso de tecnologias leves de cuidado, respeito ao protagonismo feminino, participação ativa e autonomia da mulher como impacto positivo no transcurso parturitivo. Considerações finais: a enfermeira obstétrica é uma profissional qualificada para a assistência à mulher em trabalho de parto e nascimento, porque pode favorecer a implantação e implementação do cuidado com práticas de humanização, respeito às escolhas da mulher e incentivo à via de parto normal com o olhar ampliado às necessidades individuais e multiprofissionais.

Descritores: Humanização da Assistência; Trabalho de Parto; Parto Humanizado; Enfermeiras Obstétricas; Mulheres.

\section{RESUMEN}

Objetivo: comprender las prácticas de humanización en el curso del parto desde la perspectiva de las puerperales y matronas. Métodos: investigación exploratoria, descriptiva, cualitativa, desarrollada en una maternidad del estado de Bahía. Se realizaron entrevistas semiestructuradas, con quión estructurado aplicado a 11 puerperales y 5 matronas de marzo a junio de 2019. El análisis siguió la estructura de contenido de Bardin. Resultados: el estudio reveló la importancia del uso de tecnologías de cuidado ligero, el respeto al protagonismo femenino, la participación activa y la autonomía de las mujeres como un impacto positivo en el proceso del parto. Consideraciones finales: la matronaes un profesional calificado para asistir a las mujeres en el trabajo de parto y parto, porque puede favorecer la implantación e implementación de los cuidados con prácticas de humanización, respeto a las elecciones la mujer y fomentando la forma normal de parto con mirando las necesidades individuales y multiprofesionales.

Descriptores: Humanización de la Atención; Trabajo de Parto; Parto Humanizado; Enfermeras Obstetrices; Mujeres. 


\section{INTRODUCTION}

In the prehistory of obstetrics, midwifery and the delivery process, comprehensive care for parturients with assistance to newborns was carried out by healers, midwives or humane companions. Despite the experience of these women, they were considered ignorant, which made labor assistance questionable, even the psychological help they offered at that time. Delivery and birth care was an activity devalued by the medical professional, being delegated to female care ${ }^{(1)}$.

Along the way, the care provided to women in labor underwent significant changes when labor became a hospital and surgical event, fundamental for medical knowledge, with the establishment of the medicalization of the female body. The medicalization of labor is a reflection of social medicalization, described as a complex socio-cultural process that influences the ability to cope with women's autonomy in labor and birth ${ }^{(2)}$.

Birth came to be seen as a complex, interventionist, technocratic, biomedical event, with distance from the physiology of birth, raising maternal and neonatal complications, in addition to mortality rates in Brazil, the institutionalization of labor, medicalization of the female body and advances in hard technologies, characterized by unnecessary interventions ${ }^{(3)}$.

The act of midwifery, by traditional midwives, offered assistance and attention to labor and delivery, differing from the current model. Current practices occur with many interventions, but little human warmth, and the health agents involved in this process focus more on technical results than on the expanded view of parturients ${ }^{(4)}$.

Unnecessary or excessive medical interventions and without criteria, i.e., hypermedicalization, often without clinical and diagnostic precision in the delivery period, represent a risk to maternal and neonatal health, reverberating in high mortality rates. In contrast, nurse-midwives have played an important role in humanized and qualified obstetric care in an attempt to reduce the use of invasive technologies, with care for women's needs, respect for female role and the physiology of birth ${ }^{(5)}$.

Using the term parturitive passage represents the possibility of broadening the view on women and understanding that gestating and giving birth can mean moving or going, i.e., it goes beyond a controlled, systematized, repetitive process. It concerns the existentiality and the experience of a phenomenon and requires an attentive look at practices that value female role ${ }^{(6)}$.

In this perspective, humanization in health is a strategy for valuing human dignity and the production of care, based on respect for individuality. It represents an expanded look at the exercise of ethics in order to sensitize health professionals, attentive reflection, with scientific knowledge, to welcome and respect the natural rhythm of each body ${ }^{(7)}$.

Humanizing care is recognizing individuality and establishing a bond with each woman, based on the perception of their needs and demands. It means not allowing unequal and authoritarian relations. It is the ability to deal with parturition and provide security for women and children. Moreover, the concept of humanized care in obstetric care is broad and involves a set of knowledge and practices aimed at promoting healthy labor and birth, consequently, maternal and perinatal morbidity and mortality prevention ${ }^{(8)}$.
Currently, humanization models in obstetric care have undergone significant changes in relation to values that go beyond technological and scientific aspects. Despite these advances, it is observed that the technology is not applied properly in order to obtain positive results for birth ${ }^{(4)}$.

To discuss humanization in this research, we rely on the actions of the World Health Organization (WHO) and the Pan American Health Organization (PAHO), which present Good Practices of Labor and Birth Care as an integrative phenomenon. Such an approach incorporates emotional, psychological, physiological, social and spiritual aspects, extrapolating the limiting view of biologicism, and may represent an advance in women's rights in parturition. The result of this integrative phenomenon includes the incorporation of a set of care, measures and activities that offer women a possibility of experiencing the experiences of labor and delivery as physiological experiences with positive results for mothers, newborns and family members ${ }^{(9)}$.

In this perspective, the insertion of nurse-midwives in the parturition scenario is a central possibility in humanized care practices, in guaranteeing safe and respectful care, based on Good Practices of Labor and Birth Care, with a reflection on the reduction of unnecessary and inopportune interventions, with effective communication, continuity of care, bonding, female empowerment and the reduction of maternal and neonatal morbidity and mortality rates ${ }^{(10)}$.

The care practice of nurse-midwives has enhanced professional practice performance based on obstetric practices that have been shown to be useful, prioritizing the development of skills and evidence-based techniques recommended by WHO, due to the biomedical/technocratic model. Thus, using technologies to care for women favors the physiology of birth, enhances its role and can reduce acts of intervention ${ }^{(11)}$.

We believe that nurse-mid wives are indispensable professionals in qualified obstetric care and in the implementation of care with practices that humanize labor and birth. They can strengthen and enhance autonomy and uniqueness in the parturition setting with an expanded look at the individual and multidisciplinary needs of women undergoing parturition.

\section{OBJECTIVE}

To understand humanization practices in the parturitive course from the point of view of purperae and nurse-midwives.

\section{METHODS}

\section{Ethical aspects}

This research followed Resolution 466/2012 of the Brazilian National Health Council (Conselho Nacional de Saúde) and the four basic references of bioethics: autonomy, non-maleficence, beneficence, and justice.

\section{Type of study}

This research has an exploratory, descriptive character, supported by a qualitative approach. 


\section{Methodological procedures}

\section{Study setting}

The study was conducted in the Obstetric Center (OC) with a Humanized Labor and Rooming-in Staff of a medium-complexity municipal maternity located in Bahia, in the Mid-North Bahia region, $116 \mathrm{~km}$ far from the capital Salvador. Its service structure includes emergency obstetric care, outpatient care, reception with risk stratification in obstetrics, kangaroo ward, surgical center, among others.

This study is justified by the need for transformation that emerges in labor assistance, with the reduction of caesarean sections without clinical indication. This reduction has as a consequence the increase in maternal and neonatal morbidity and mortality rates, complications secondary to the procedure, such as puerperal infections, increased risk of lower limb thrombosis, hemorrhages, anesthetic accidents, prolonged recovery and incidence of postoperative pain, risk for newborn, in addition to presenting respiratory distress soon after birth ${ }^{(12)}$.

We defend, therefore, that the possibilities for this transformation lie in Good Labor and Birth Practices. Humanization in the delivery period needs attention, since in 2016 Brazil presented 1,670 cases of maternal deaths during pregnancy or puerperium, with 493 deaths during pregnancy, labor or abortion; 972 during puerperium, up to 42 days; 74 during puerperium, from 43 days to less than 1 year; 34 not related to pregnancy or puerperium; 97 cases not reported or ignored. In Bahia State, in 2016, there were 122 maternal deaths and 14 late deaths. Concerning neonatal deaths (up to 27 days of life), they totaled 2,381 in the same year. Among the municipalities, Salvador had the highest number of deaths, with 22 maternal deaths and 6 late deaths ${ }^{(13)}$.

According to data from the Mortality Information System (SIM - Sistema de Informação de Mortalidade), in 2018, the municipality studied recorded 11 cases of maternal deaths. In 2019, in the first six months, 09 cases were recorded, which include deaths caused by problems related to pregnancy, labor or occurring up to 42 days after work $^{(14)}$.

\section{Data source}

Thus, 16 people participated in this research. Of these, 11 puerperae who experienced normal birth, over 18 years old. Women with absolute indications for cesarean sections and in an abortion situation were not included. Also, 5 nurse-midwives from $\mathrm{OC}$, linked to this sector with a period of more than 6 months were included. Nurses on maternity leave or on leave due to other conditions were not included.

\section{Data collection and analysis}

Data collection took place from March to June 2019 by using semi-structured interviews. The data collection instrument followed a semi-structured script for puerperae, consisting of six items. The first, with participants' data characterization with codename, age, and color referred; the second, with socioeconomic characterization according to items from the Brazilian Institute of Geography and Statistics (IBGE - Instituto Brasileiro de Geografia e Estatística); the third, with gynecological-obstetric data; the fourth, with the guiding question: what do you understand by humanization at work? For nurse-midwives, two items: socioeconomic characterization data and the guiding question: talk about humanization at work and birth.

The interviews recorded on a smartphone device were carried out in private rooms at the maternity hospital according to participants' availability, recorded with consent following the description of the Informed Consent Term (ICF). The interviews' transcripts demanded effort to preserve the fidelity of participants' language, gestures, and non-verbal expressions.

Analysis followed the structure of Bardin's content analysis composed of pre-analysis, material exploration, treatment of results, inference and interpretation. Analysis makes it possible not only to trace ways of understanding the collected data, but to build, expand or even shed light on a specific field of knowledge.

Pre-analysis corresponded to the period of intuitions, aiming at making operational and systematizing the initial ideas, in order to conduct the research. In this stage, the interviews were read and reread, cutting and selecting the statements that were included in data interpretation.

The subsequent stage, defined as material exploration, corresponded to the systematization of the collected data. An analytical framework was constructed in order to contain the core of meanings and the unit of analysis, in order to systematize and consolidate the data, with representation of the first inferences and subsequent construction of the analytical categories.

Finally, the third step, which consists of treating and interpreting the data obtained, represents an attentive look at the first inferences. At that moment, reading the analytical framework was deepened with a look at the excerpts of all statements, with the emergence of analytical categories and their relationship with scientific productions that can contribute to the consolidation of reliable results and the construction of new knowledge on the practice of humanization in the parturitive course from the perspective of puerperae and nurse-midwives ${ }^{(15)}$.

Six categories emerged, being distributed as follows: 3 for puerperae: Humanization of labor as a strategy for the technocratic model cross-section in obstetrics; Physiology of birth, the female role and Good Practices of Labor and Birth Care; Recognition of nurse-midwives in the defense and respect for humanization practices for women undergoing parturition; 3 for nurse-midwives: Working conditions and humanization practices at work and birth: Prenatal care and giving a new meaning to the experience in the parturitive course; In defense of the physiology of normal work: a look with possibilities and limits.

\section{RESULTS}

\section{ANALYTICAL CATEGORIES - PUERPERAE}

The age of puerperae varied between 19 and 37 years. It was observed that the highest frequency occurred in the age group of 31 years (18.2\%). The referred skin color, according to IBGE items, sought to identify ethnic-social aspects and self-declaration, with the following classification indexes: $54.5 \%$ mixed-race, $27.3 \%$ black, $18.2 \%$ white and yellow.

The socioeconomic characterization in this research refers to the level of education, profession, occupation, and marital status. 
Concerning education, $54.5 \%$ of these puerperae attended high school, 36.4\% completed higher education and, of these, only $9.1 \%$ attended the $1^{\text {st }}$ to $5^{\text {th }}$ year of elementary school.

Data showed that more than half of puerperae have a profession with low social and/or economic status such as attendants, scale operators, general service workers, beauty area professionals, bookkeeping, among others. On the other hand, when investigating their occupation, $72.7 \%$ reported being housewives and $27.3 \%$ denied having any occupation.

As for marital status, $72.7 \%$ declared themselves single, but with a stable union, and $27.3 \%$ were married. This data signals the importance of a comprehensive and welcoming assistance during parturition. The possibility of including their partners in this process at this time is suggested, in order to strengthen bonds at birth.

In the gynecological-obstetric history, $36.4 \%$ are primiparous; $45.4 \%$ are pregnant women; $9.1 \%$ have three children; $9.1 \%$ are multigravida with five or more pregnancies. Regarding the labor route, $100 \%$ reported having vaginal labor in all their pregnancies.

From the guiding question, the analytical categories emerged:

\section{Humanization of labor as a strategy for the technocratic model cross-section in obstetrics}

Humanization practices in the parturitive course emerge as a proposal to mainstream the technocratic model, with the rescue of autonomy, female empowerment, active participation, with a view to ensuring respect for the physiology of labor and birth, in defense of an attentive look at practices that value the role of women in decisions about their bodies.

[...] the first labor was induced. [...] in the case of my daughter, it was different, there was no serum, I was not induced, I was not cut, so it was really, in my view, the real natural work. (FLEUR-DE-LYS)

[...] for me, humanization at work is participation in choosing a position. [...] you are there aware of what is happening, with the participation of the father or the companion [...] you are participating, you are witnessing, so for me the humanized work is you having choices. (LAVANDER)

\section{Physiology of birth, the female role and Good Practices of Labor and Birth Care}

With an attentive eye to puerperae' statements, some axes emanating from humanized practices during labor, we can take a chance on affirming that there is already a cross-cutting between the technocratic model and the good practices model.

[...] my baby was born without serum. [...] I had my little baby on the stool. I loved this method because I sat on the stool and my husband was behind me, hugging me, so he really participated. (HYDRANGEA)

[...] he gave me coconut water, chocolate, juice, he even had a massage. [...] he put me on that stool and helped me to push until my baby left, and they put it on my belly. [...] and about the stool I loved it because it was better than in bed, they put me in bed and I didn't have enough strength. (LILY)

\section{Recognition of nurse-midwives in the defense and re- spect for humanization practices for women undergoing parturition}

Nurse-midwives can be leading actors of Good Labor and Birth Practices as active agents and propitiate the reduction of unnecessary interventions, with guarantee of the normal work path and execution of humanized practices.

[...] it was a good, normal job. It wasn't very painful because I got the attention of the nurses, the staff on duty. (DAISY)

[...] a physician and a nurse-midwife gave me all support, they told me that it is my and my baby's time to be born. They were not going to do any intervention. [...] my baby didn't have any intervention; they didn't take it. (ORCHID)

\section{ANALYTICAL CATEGORIES - NURSE-MIDWIVES}

The age of nurse-midwives ranged between 29 and 37 years. The highest frequency occurred in the age group of 29 years with the percentage equivalent to $17.3 \%$ of the total of this group.

Concerning skin color, $100 \%$ of participants declared themselves to be mixed-race, following the IBGE classification guidelines.

In this research, socioeconomic characterization refers to the level of education of participants. According to the data collected, it is possible to state that $100 \%$ of nurse-midwives rose to the degree of specialist in obstetrics, a result that may be related to the specificity of the place that served as the setting for this research, which prioritizes qualification by specialty.

From the perspective of nurse-midwives, it was possible to understand humanization practices in the parturitive course from the analytical categories:

\section{Working conditions and humanization practices at work and birth: a fragile relationship}

The fragile relationship of working conditions with regard to the implementation of humanization practices for women in labor makes the need for interventions that guarantee the provision of obstetric care centered on the possibility of structural resolution, in order to guarantee quality of care equitable and not unequal to parturients waiting for bed.

[...] is it also humanizing those outside? To respect? [...] what can we do to ensure that the patient is respected? May it also help her to evolve this labor work? So that patients, who also need to enter maternity, have the same right to be respected? [...] have the same right to have your children in a respectful way? [asks the interviewee]. (GREAT KISKADEE)

[...] it happened on my shifts that I had to get a patient out of bed, put her sitting on a chair because there was a patient in the corridor sitting on active labor, and I had to get the patient out of bed. [...] this is totally inhuman. [...] having to get a patient out of bed, put her sitting, so she can put the other one to give birth, clean the bed and put it back from the chair to the bed. (SWALLOW) 


\section{Humanized prenatal care and giving a new meaning to the experience in the parturitive course}

Nurse-midwives contextualize the importance of prenatal support in the quality of guidelines about giving a new meaning to normal work, of obstetric practices beneficial to maternal and neonatal health, in an attempt to guarantee the possibility of a positive parturitive course.

[...] how are we going to approach the patient to give that assistance, give guidance during labor? [...] did this patient have prenatal care or not? If she did prenatal care, was she informed during prenatal care what a job really is? (HAWK)

[...] we know that most patients do not arrive prepared for humanized work. Many patients complain about obstetric violence. They don't know what labor is. [...] the patient who comes to us does not know that giving birth hurts, that giving birth takes time. [...] sometimes the patient arrives, and she wants to give birth soon. [...] if I'm already working, I have to give birth. [...] there is a patient who arrives, the water broke for two hours, he thinks the baby is going to die. [...] she knows what obstetric violence is, but she doesn't know how to humanize labor. (EAGLE)

\section{In defense of the physiology of normal work: a look with possibilities and limits}

The statements indicate the participation of nurse-midwives in defense of qualified care for the puerperal pregnancy cycle, as well as respect for physiology of normal work and the rescue of the female role as positive possibilities for the parturition process; at the same time, they recognize the difficulties in the institutional spheres, whose different points need to meet in an attempt to reorganize, dynamize and strengthen the service in its entirety.

[...] when people talk about humanized labor, it seems that the work is for nurse-midwives, it is for obstetricians, no! [...] the leading role of the labor belongs to women! [...] in that scenario there, who is the leading actor of the scene in labor? Women! (HAWK)

[...] when we entered the perspective of humanized labor within the obstetric center, the medical staff thought that this was a fad. [...] you see that you will not be born well? [...] the medical staff has greatly improved these interventions, but in some cases, it ends up interfering, causing premature rupture of the bags artificially, induction with oxytocin even if the patient has effective contractions, but they want them to contract a little more so that it evolves faster. (GREAT KISKADEE)

\section{DISCUSSION}

The humanization of work is presented as a set of practices and actions discussed in line with women, in order to promote the role and empowerment of women, in harmony, taking into account their emotional state, their beliefs, exaltation of their dignity and autonomy, with the purpose of improving assistance in labor and birth. The aim, therefore, is to avoid unnecessary and untimely technocratic, interventionist actions, in defense of practices based on scientific evidence committed to the wellbeing of women, newborns and family, as well as the reduction of maternal and neonatal mortality ${ }^{(16)}$
In this perspective, the cross-section of the current biomedi$\mathrm{cal} /$ technocratic model has demanded efforts in the sense that these practices are reduced. Thus, it is possible to give space to humanized care with an appreciation of parturients' needs, with the rescue of their autonomy and female role, as well as knowing their rights and knowledge in care practices for themselves and their newborns ${ }^{(17)}$.

From the point of view of puerperae, humanization in the parturitive process makes it possible to mainstream the current model towards Good Labor and Birth Practices with: conduct and attitudes based on soft care technologies; respect to the physiology of birth; individuality; autonomy that goes beyond the limiting view of biologicism in defense by looking closely at practices that value the role of women in their decisions; negligence reduction, obstetric violence; increase in maternal and neonatal morbidity and mortality rates.

For nurse-midwives, when considering incorporating Good Practices of Labor and Birth Care and consequently reducing unnecessary interventions constituted in $\mathrm{WHO}$ recommendations and reinforced by the Ministry of Health $(\mathrm{MoH})$, through a policy called Stork Network (Rede Cegonha), which seeks to qualify obstetric care with the reduction of negative maternal and perinatal outcomes, as well as the strengthening of autonomy and the female role in its multiple dimensions and the encouragement of bonding, empathy and welcoming, in addition to awareness of demedicalization and unsuitable practices, we can believe that we are on the right path ${ }^{(5)}$.

Regarding the concept of Good Labor and Birth Practices, which, to a certain extent, orbits this research, puerperae's statements defend the demedicalization, the stimulation to verticalization, the presence of the companion and early skin-to-skin contact with newborns right after birth. Thus, we observe the importance of soft technologies, non-invasive to parturition and birth as beneficial to mothers, newborns, and family.

This research points to the recognition of nurse-midwives in the parturition scenario as an adjunct to respect for the physiology of birth with the implementation of humanization practices in detriment to the reduction of unnecessary and untimely interventions.

On the other hand, the view of nurse-midwives on humanization practices and working conditions makes the need for interventions that guarantee obstetric care provision focused on the possibility of institutional and user resolution from the perspective of enabling, starting from of this reflection, an equitable, human assistance, looking for conditions to welcome parturients waiting for beds.

Among so many other possible aspects, there is a need to expand the look at the discussions of institutional violence due to inadequate infrastructure and lack of human and material resources in favor of a safe motherhood that allows the exercise of equality and dignity of women in parturition based on scientific evidence and humanized assistance to labor and birth ${ }^{(18)}$.

There is a fragile relationship between working conditions, overcrowding in institutions and humanization practices during parturition to guarantee the physiology of birth. Along this path, we defend awareness, commitment and social responsibility with labor and birth as a factor of change in health systems and society. 
Another highlight in the view of nurse-midwives was the importance of prenatal support in the quality of the orientations about giving a new meaning to normal work in its physiological dimension for strengthening obstetric practices beneficial to maternal and neonatal health, in an attempt to guarantee the possibility of a positive parturitive course and health education practices with a humanistic and scientific look at the demands of parturients, their concept and family.

Therefore, we can say that despite the advances and achievements in public policies for women's health, there are still gaps regarding the way in which women perceive the meaning of gestating and giving birth to presumed meanings of terms such as labor and birth, humanization, and physiology of birth.

In order for there to be obstetric care in defense of the physiology of birth, the staff involved in the parturition scenario can discuss and strengthen Good Practices of Labor and Birth Care in order to avoid unnecessary interventions and reduce risks for the promotion of women's autonomy and privacy; active participation in decisions related to the care provided; possible changes in behavior to defend the guarantee of the right to safe care for mothers and their newborns ${ }^{(5)}$.

Therefore, it is recognized the participation of nurse-midwives in support of qualified attention to the puerperal pregnancy cycle, as well as respect for the physiology of normal work and the rescue of the female role as positive possibilities for the parturitive course.

\section{Study limitations}

The limitations of this research were due to the impossibility of the interviews being with the whole body of nursing professionals, there was a refusal of some people to participate in the research and because it was carried out only at a maternity hospital.

\section{Contributions to nursing and health}

This research contributes in the social sphere of health services, academia and nursing to motivate nursing professionals, medical staff and institutions. It allows reflections for an attentive look at humanization practices in the parturitive course, from the physiology of respectful birth, in order to enable changes to the biomedical/technocratic model. In the academic field, it has the possibility of motivation to carry out new research in the field to contribute to producing scientific knowledge in undergraduate and graduate courses in nursing.

\section{FINAL CONSIDERATIONS}

The research defends the importance of incorporating the Good Practices of Labor and Birth Care categories recommended by the WHO based on scientific evidence for assistance in the delivery process. Thus, the biomedical/technocratic model cross-section in defense of the physiology of birth would be allowed, recommending spaces for listening pregnant women about themselves and decisions about their bodies.

The reduction of unnecessary and inopportune interventions in Brazil, with relevance for the implementation of humanization at birth, is closely associated with the capacity of nurse-midwives to strengthen soft care technologies in the rescue during birth. This occurs as a natural and physiological event, with obstetric practices useful with non-harmful interventions and actions, as opposed to the technocratic model of care, in an attempt to strengthen humanization practices for labor and birth.

In this regard, soft technologies of care are related to the development of humanized practices, beneficial when pregnant and giving birth, non-invasive to the physiology of birth, with guarantee of respect for the female body, privacy, uniqueness, and autonomy.

This research pointed out the importance of nurse-midwives to continue executing obstetric practices humanized to the parturitive course as a tool for the biomedical/technocratic model cross-section to the physiology of birth, female role and use of Good Practices of Labor and Birth Care. Puerperae recognize the experiences of parturition as experiences full of quality information, uniqueness, satisfaction, security and humanization.

In this way, nurse-midwives make it possible to advance comprehensive and humanized care for women in labor, guarantee the rights of choice, respect for singularity and subjectivity, qualified listening, female role, security as well as the de-medicalization of labor and birth. Thus, an attentive look and sensitive listening are encouraged, aiming at obstetric practices that are demonstrably useful and beneficial, which ensure the valorization of normal birth.

\section{REFERENCES}

1. Sena CD, Santos TCS, Carvalho CMF, Sá ACM, Paixão GPN. Avanços e retrocessos da enfermagem obstétrica no Brasil. Rev Enferm UFSM [Internet]. 2012 [cited 2019 Jul 23];2(3):523-9. Available from: https://periodicos.ufsm.br/reufsm/article/view/3365/pdf

2. Leão MRC, Riesco MLG, Schneck CA, Angelo M. Reflexões sobre o excesso de cesarianas no Brasil e a autonomia das mulheres. Rev Ciên Saúde Colet [Internet]. 2013 [cited 2018 Aug 01];18(8):2395-400. Available from: http://www.scielo.br/pdf/csc/v18n8/24.pdf

3. Silva TC, Bisognin P, Prates LA, Wilhelm LA, Bortoli CFC, et al. As Boas Práticas de Atenção ao Parto e ao Nascimento sob a ótica de enfermeiros. Biblioteca Las Casas - Fundación Index [Internet]. 2016 [cited 2017 Jun 12];12(1). Available from: http://www.index-f.com/ lascasas/documentos/lc0886.pdf

4. Pimenta DG, Azevedo BAMC, Silva OLT, Gomes XMSC. Parto realizado por parteiras: uma revisão integrativa. Rev Eletrôn Trim Enferm [Internet]. 2013 [cited 2017 Jan 13];30:494-505. Available from: http://scielo.isciii.es/pdf/eg/v12n30/pt_enfermeria2.pdf

5. Pereira SB, Diaz CMG, Backes MTS, Ferreira CLL, Backes DS. Boas práticas de atenção ao parto e ao nascimento na perspectiva de profissionais de saúde. Rev Bras Enferm. 2018;71(Suppl 3):1313-9. doi: 10.1590/0034-7167-2016-066 
6. Moreira RCR. Trilhando o método de investigação em Heidegger: etapas de análise aplicadas à obstetrícia. Feira de Santana: UEFS, 2016.

7. Alves DFC, Mourão LF, Marques ADB, Branco JGO, Cavalcante RC, et al. Processo de humanização na assistência de enfermagem à parturiente: revisão integrativa. Sanare, Sobral [Internet]. 2017 [cited 2018 Feb 20];16(02):68-76. Available from: https://sanare.emnuvens. com.br/sanare/article/view/1180/641

8. Ministério da Saúde (BR). Secretaria de Políticas de Saúde. Área Técnica de Saúde da Mulher. Parto, aborto e puerpério: assistência humanizada à mulher. Brasília: Ministério da Saúde [Internet]. 2001 [cited 2017 Jul 21]. Available from: http://bvsms.saude.gov.br/bvs/ publicacoes/cd04_13.pdf

9. Ministério da Saúde (BR). Humanização do parto e do nascimento. Brasília: Ministério da Saúde, 2014.

10. Amaral RCS, Alves VH, Pereira AV, Rodrigues DP, Silva LA, et al. A inserção da enfermeira obstétrica no parto e nascimento: obstáculo em um hospital de ensino no Rio de Janeiro. Rev. Esc. Anna Nery. 2019;23(1):e20180218. doi: 10.1590/2177-9465-EAN-2018-0218.

11. Duarte MR, Alves VH, Rodrigues DP, Souza KV, Pereira AV, Pimentel MM. Tecnologias do cuidado na enfermagem obstétrica: contribuição para o parto e nascimento. Rev Cogitare Enferm. 2019;24:54164. doi: 10.5380/ce.v24i0.54164

12. Mascarello KC, Horta BL, Silveira MF. Complicações maternas e cesárea sem indicação: revisão sistemática e meta-análise. Rev Saúde Publica [Internet]. 2017 [cited 2018 Jul 26];51:105. Available from: http://www.scielo.br/pdf/rsp/v51/pt_0034-8910-rsp-S1518-87872017051000389.pdf

13. Ministério da Saúde (BR). Departamento de Informática do SUS. Informações de saúde: mortalidade. Brasília: Ministério da Saúde [Internet]. 2016 [cited 2017 Mar 19]. Available from: http://www2.datasus.gov.br/DATASUS/index.php?area=0205

14. Bahia. Hospital Estadual da Criança. Serviço de arquivo médico e estatístico. Feira de Santana: HEC, 2019.

15. Bardin L. Análise de conteúdo. São Paulo: Edições 70; 2011.

16. Cordeiro ELA, Silva TM, Silva LSR, Veloso ACF, Pimentel RVT, Cabral MMO, et al. A humanização na assistência ao parto e ao nascimento. Rev Enferm UFPE. 2018;12(8):2154-62. doi: 10.5205/1981-8963-v12i8a236334p2154-2162-2018

17. Alvares AS, Corrêa ÁCP, Nakagawa JTT, Teixeira RC, Nicolini AB, Medeiros RMK. Práticas humanizadas da enfermeira obstétrica: contribuições no bem-estar materno. Rev Bras Enferm. 2018;71:2620-27. doi: 10.1590/0034-7167-2017-0290

18. Marrero L, Brüggemann OM. Violência institucional durante o processo parturitivo no Brasil: revisão integrativa. Rev Bras Enferm. 2018;71(3):1152-61. doi: 10.1590/0034-7167-2017-0238 